\title{
Two Independent Quantitative Trait Loci Are Responsible for Novel Resistance to Beet curly top virus in Common Bean Landrace G122
}

\author{
Richard C. Larsen, Chester J. Kurowski, and Phillip N. Miklas
}

First and third authors: U.S. Department of Agriculture, Agricultural Research Service, Vegetable and Forage Crop Research Unit, 24106

North Bunn Road, Prosser, WA 99350; and second author: Harris Moran Seed Company, 9241 Mace Blvd., Davis, CA 95616.

Current address of C. J. Kurowski: Monsanto Vegetable Seeds, 37437 State Highway 16, Woodland, CA 95696.

Accepted for publication 24 May 2010.

\begin{abstract}
Larsen, R. C., Kurowski, C. J., and Miklas, P. N. 2010. Two independent quantitative trait loci are responsible for novel resistance to Beet curly top virus in common bean landrace G122. Phytopathology 100:972-978.

Beet curly top virus, often referred to as Curly top virus (CTV), is an important virus disease of common bean in the semiarid regions of the United States, Canada, and Mexico and the only effective control is genetic resistance. Our objective was to determine if dry bean landrace G122, which lacks the Bct gene for resistance to CTV, contains novel resistance to the virus. Two populations, GT-A and GT-B, consisting of $98 \mathrm{~F}_{5: 7}$ recombinant inbred lines (RILs) in total were derived from a cross between G122 and the susceptible variety Taylor Horticultural and evaluated for phenotypic response to natural CTV field infection. Genetic

analyses revealed random amplified polymorphism DNA (RAPD) markers associated with a major-effect quantitative trait loci (QTL) from G122 which exhibited stable expression across 3 years in both populations. Phenotypic variation explained by the QTL in GT-A (37.6\%) was greater than in GT-B (20.4\%). RAPD marker Q14.973 was converted to a sequence-characterized amplified region (SCAR) and designated SQ14.973. The SCAR was used to locate the QTL on linkage group 6 of the Phaseolus core map. A survey of 74 common bean cultivars and breeding lines revealed SQ14.973 would be widely useful for markerassisted selection of the QTL. An additional minor-effect QTL from G122 was detected on linkage group 7. G122 was determined to possess novel resistance to CTV conditioned by at least two genes, one with major the other minor effect.
\end{abstract}

Beet curly top virus (BCTV) (family Geminiviridae, genus Curtovirus) causes a serious disease for common bean (Phaseolus vulgaris L.) produced in the semiarid regions of the western United States, Canada, and Mexico. BCTV has been recognized as a significant plant pathogen of many other agricultural crops since 1899 (2) and is known to infect a broad range of crop and weed hosts representing 44 plant families (1). Other crop hosts for which natural BCTV infection have been reported include cucurbits, sugar beet (Beta vulgaris), pepper (Capsicum spp.), spinach (Spinacia oleracea), and tomato (Lycopersicon esculentum) $(1,3)$.

BCTV historically has been known to consist of many strains that are comprised of variants of the closely related Worland, Logan, and CFH strains based on their respective mild, intermediate, and severe symptom expression in sugar beet $(14,15,19)$. As a result of complete molecular characterization of the genomes reported by Stenger and McMahon (18), the strains are now considered three distinct viruses following species demarcation guidelines set forth by the International Committee on Taxonomy of Viruses (4). The Logan strain was named Beet curly top virus (BCTV) and is the type species of the genus, Worland = Beet mild curly top virus (BMCTV), and $\mathrm{CHF}=$ Beet severe curly top virus (BSCTV) (14,16-18). Symptom demarcation among BCTV, BMCTV, and BSCTV infection in common bean is not readily apparent, as all three viruses cause severe symptoms in this host. Consequently, the causal pathogen of curly top disease in common bean, due to infection by one or more of these viruses, is

Corresponding author: P. N. Miklas; E-mail address: Phil.Miklas@ars.usda.gov

doi:10.1094/PHYTO-02-10-0049

This article is in the public domain and not copyrightable. It may be freely reprinted with customary crediting of the source. The American Phytopathological Society, 2010. collectively referred to as Curly top virus (CTV). Infection in susceptible common bean causes leaf malformation, curling, chlorosis, leatheriness, and severe stunting of the plant (13). During severe CTV epidemics, highly susceptible bean cultivars can result in total crop loss if infected early (13). Bean plants infected soon after emergence die quickly and casual observation of plants in the field resemble death caused by root rotting pathogens.

CTV is vectored in a persistent manner by the beet leafhopper Circulifer tenellus (Baker) in North America. In the dry areas of the Pacific Northwest, leafhoppers acquire the virus from Russian thistle (Salsola kali L.), tumble mustard (Sisymbrium altissimum L.), and other weed hosts in the early spring (13). Control of the leafhopper by postemergence insecticide applications is ineffective because the vector does not colonize common bean. Although seed treatments containing systemic insecticides appear to provide some protection, the most effective control of CTV in bean is obtained by deployment of natural genetic resistance found in the host.

The origin of CTV resistance in common bean traces back to two prominent sources, the Common Red landrace cultivar and 'Burtners Blightless', a small white cultivar. Early inheritance studies (12) showed that resistance in common bean was conditioned by two genes, one dominant and one recessive. Larsen and Miklas (6) identified a sequence-characterized amplified region (SCAR) marker (SAS8.1550) tightly linked to the original dominant gene Bct conferring resistance to CTV. The marker was used to place Bct on linkage group 7 of the Phaseolus core map. During screening procedures to evaluate the robustness of SAS8.1550 for marker-assisted selection (MAS) purposes, the landrace cv. Jatu Rong (PI 163120 with the corresponding CIAT accession catalog number G122) from India was the only geno- 
type from the Andean gene pool with resistance to CTV that lacked the marker (6). The objective of this research was to determine whether G122 possesses novel resistance to CTV.

\section{MATERIALS AND METHODS}

Preliminary study. To first determine whether resistance to CTV in G122 was independent of the Bct gene, an $\mathrm{F}_{2}$ population was derived from a cross between G122 and 'Cardinal' cranberry bean. G122 exhibits resistance to CTV but lacks the SAS8.1550 SCAR marker linked with Bct (6). Cardinal cranberry bean possesses resistance to CTV conferred by the Bct gene that is linked to the SAS8.1550 SCAR marker (unpublished data).

Ninety $F_{2}$ plants of the $\mathrm{G} 122 \times$ Cardinal cross were rated for disease reaction 14 days after inoculation by Agrobacterium tumefaciens infected with a CTV clone developed for the Harris Moran Seed Company by D. Bisaro at Ohio State University. The inoculation procedure is a proprietary method developed by $\mathrm{C}$. Kurowski. The agro-test is well suited for evaluating genetic populations because few plants escape infection; whereas, some plants are more likely to escape natural infestation in the field. Plants with no symptoms were rated as resistant, and plants with obvious leaf curling, leaf chlorosis, and plant stunting were considered susceptible. Plants with mild symptoms were considered moderately susceptible. Observed segregation of 79 resistant, 5 moderately susceptible, and 6 susceptible $F_{2}$ plants, provided initial evidence that G122 likely possessed resistance independent of the Bct gene. This preliminary finding provided impetus for further exploring the inheritance of resistance in G122 using a recombinant inbred line (RIL) population.

Population development. Two populations of $\mathrm{F}_{5}$-derived $\mathrm{F}_{7}$ $\left(F_{5: 7}\right)$ RILs were developed from separate $F_{1}$ seed obtained from different crosses made between G122 $\times$ Taylor Horticultural (henceforth referred to as the GT RIL populations) by the singleseed descent breeding method. The populations, referred to as GT-A and GT-B, were comprised of 52 and 46 RILs, respectively. G122 exhibits an immune response to natural CTV epidemics in Washington State, while Taylor Horticultural is highly susceptible.

Field experiments. GT RIL populations GT-A (52 RILs) and GT-B (46 RILs) were tested in separate experiments planted adjacently to one another at the Washington State University Roza Research Farm in Prosser, WA. In addition to the RILs, each experiment contained both parents G122 and Taylor Horticulture. The experiments were conducted during three subsequent years from 2006 to 2008. Each year a different field on the same research farm was used for the plantings. Each experiment was planted in a randomized complete block design with three replications used in 2006 and 2007 and two replications in 2008. A plot (experimental unit) consisted of a single row $3 \mathrm{~m}$ in length sown with approximately 40 seeds of an individual RIL or parent. Spacing between plots (rows) was $0.56 \mathrm{~m}$. The fields were irrigated and fertilized as needed and weeds were controlled to promote optimum growing conditions for the test plants.

A simple disease rating system of resistant (R) or susceptible (S) was used to evaluate infected plants for each plot. This system was possible because of the lack of intermediate responses to CTV infection in the RIL populations. The CTV incidence was based on the total number of infected plants within a plot which was comparable to the number of susceptible plants based as a percentage of the total plants within a plot (data not shown). Given that incidence based on number of infected plants is less cumbersome to obtain than incidence based on percentage infection, the former measurement was used for subsequent analyses. Plants were evaluated several times over the growing season for number of infected plants, but only the final evaluation conducted at mid-pod fill growth stages R3 to R5 is reported herein. Certain plants exhibiting ambiguous symptoms of CTV had leaf samples evaluated for presence or absence of the virus using the direct enzyme-linked immunosorbent assay (ELISA) system for geminiviruses (Agdia, Elkhart, IN) according to the manufacturer's instructions.

Nucleic acid preparation. Four seeds from each of the 98 GT RILs were planted in the greenhouse for use in DNA extractions. Leaf tissue (approximately $125 \mathrm{mg}$ ) from emerging trifoliates were collected from each of the four plants of each line evaluated and placed in tissue maceration tubes supplied in the FastDNA extraction kit (MP Biomedicals, Solon, OH). Genomic DNA was extracted from samples according to the manufacturer's instructions. The DNA bound to the matrix was recovered by eluting with $150 \mu \mathrm{l}$ of sterile water. DNA was quantified using a NanoDrop Spectrophotometer (Thermo Fisher Scientific, Wilmington, DE) and then diluted to a final working concentration of $10 \mathrm{ng} / \mu \mathrm{l}$ for subsequent polymerase chain reaction (PCR).

Random amplified polymorphism DNA marker assays. Bulked-segregant analysis was used to screen for random amplified polymorphism DNA (RAPD) markers linked with disease reaction segregating in the GT RIL populations based on disease incidence observed in the 2006 experiments. Three DNA bulks were formed and were comprised of six resistant lines exhibiting low disease incidences ranging from 0 to 1 infected plants representing population A, six resistant lines with similarly low disease incidences representing population $\mathrm{B}$, and six susceptible lines with high disease incidences, three from each population. RAPD primers (Operon Technologies, Inc., Alameda, CA) were screened for polymorphisms, primarily as bands present after agarose gel electrophoresis of PCR products, in the resistant population A and B DNA bulks but absent in the susceptible DNA bulk. RAPDs detected between the $\mathrm{R}$ and $\mathrm{S}$ bulks that cosegregated $(>75 \%)$ with disease reaction across the 18 RILs comprising the three DNA bulks were assayed across each of the individual 98 RILs.

PCR was conducted in $25-\mu \mathrm{l}$ volumes containing $50 \mu \mathrm{g}$ of template DNA, 1× GoTaq PCR buffer (Promega Corp.), $3 \mathrm{mM}$ $\mathrm{MgCl}_{2}, 100 \mu \mathrm{M}$ each of dATP, dCTP, dGTP, and dTTP, $15 \mathrm{ng}$ of decamer primer, and 1.25 units of GoTaq DNA polymerase. Thermocycling parameters consisted of a single cycle of $2 \mathrm{~min}$ at $95^{\circ} \mathrm{C}$ and then 40 cycles of $1 \mathrm{~min}$ at $94^{\circ} \mathrm{C}, 1 \mathrm{~min}$ at $37^{\circ} \mathrm{C}$, and $1 \mathrm{~min}$ at $72^{\circ} \mathrm{C}$. Amplified products from all PCR assays were separated on $1.5 \%$ agarose gels containing ethidium bromide $(0.5 \mu \mathrm{g} / \mathrm{ml})$ for $3.5 \mathrm{~h}$ at $6 \mathrm{~V} / \mathrm{cm}$ constant voltage in TBE buffer (89 mM Tris, $89 \mathrm{mM}$ boric acid, and $2 \mathrm{mM}$ EDTA, final $\mathrm{pH} 8.3$ ).

QTL analysis, SCAR development, and linkage mapping. Regression analysis of selected RAPD markers on disease incidence phenotype was conducted using the general linear models procedure (PROC GLM) by SAS (SAS Institute, Cary, NC) (11). A probability level of $<0.05$ was used as a significance level to declare presence of QTL. This analysis was conducted separately for each GT RIL population in order to detect QTL across separate meiotic events. In addition, data for each year were analyzed separately in order to examine environmental stability of the detected QTL. Multiple regression was used to examine interactions among independent QTL.

Informative RAPD markers as determined by the QTL analysis were selected as candidate markers for SCARs. DNA was excised and recovered from agarose gels using Gene Capsule (Geno Technology Inc., St. Louis, MO) as directed by the manufacturer's instructions. The PCR products were cloned into the plasmid vector pCR4-TOPO (Invitrogen, Carlsbad, CA) according to the manufacturer's instructions. Plasmid DNA was isolated from transformed E. coli by the alkaline lysis method (10) and then digested with EcoRI, and the restriction digestion products were visualized by gel electrophoresis to identify clones containing the PCR products. The DNA products were sequenced using the dideoxy-chain termination method prior to designing extended SCAR primer pairs. 
The JoinMap 4 software program (20) was used to develop linkage groups based on the RAPD or SCAR marker assays for the combined 98 RILs of both populations. Markers were assigned to a group based on an independence LOD score of 5.0. Linkage order was determined by the 'Regression' mapping algorithm option with default settings and Kosambi mapping function. The linkage groups possessing QTL were integrated with the Phaseolus core map by assaying RAPD and SCAR markers in the BAT93/Jalo EEP558 (BJ) (5) or A55/G122 (AG) (7) RIL mapping populations. There were $80 \mathrm{BJ}$ and $67 \mathrm{AG}$ RILs assayed for select markers from the GT linkage groups. The RIL populations, including marker data sets, were courtesy of P. Gepts, University of California, Davis.

A few of the QTL-linked markers were assayed across a group of dry bean and snap bean genotypes including cultivars, germplasm lines, and advanced breeding lines to gauge potential utility for MAS of the G122-derived CTV resistance in common bean.

\section{RESULTS AND DISCUSSION}

Infection pressure was uniform across all 3 years as indicated by the high level of disease incidence for the susceptible parent Taylor Horticultural (Table 1). Taylor Horticultural and other susceptible lines within the two RIL populations exhibited severe symptoms characteristic of early CTV infection. Conversely, only occasional plants infected with CTV as verified by ELISA occurred each year within plots of the resistant parent G122.

The frequency distributions of RILs for mean disease incidence were similarly skewed toward resistant reactions across populations and years (Fig. 1). The skewed distribution suggests multiple genes with major effects condition resistance (lower disease incidence). RILs with disease incidences from 0 to 2 infected plants appeared resistant in the field and distinguished from RILs with incidences $>2$ infected plants exhibiting intermediate to susceptible reactions. Using this demarcation of 0 to 2 as resistant and $>2$ as intermediate or susceptible, the proportion of the GT-A and

TABLE 1. Mean disease incidence for Curly top virus observed for two recombinant inbred line (RIL) populations (GT-A and GT-B) derived from separate $F_{1}$ plants from the cross G122 $\times$ Taylor Horticulture tested in adjacent field trials for 3 years

\begin{tabular}{lccc}
\hline \multirow{2}{*}{$\begin{array}{l}\text { GT RIL populations } \\
\text { and parents }\end{array}$} & \multicolumn{3}{c}{ Mean number of infected plants } \\
\cline { 2 - 4 } & 2006 & 2007 & 2008 \\
\hline GT-A (52 RILs) & 4.3 & 4.5 & 3.6 \\
G122 & 0.7 & 0.0 & 0.0 \\
Taylor Horticultural & 7.7 & 12.3 & 8.5 \\
GT-B (46 RILs) & 2.8 & 2.7 & 3.1 \\
G122 & 0.0 & 1.0 & 1.0 \\
Taylor Horticultural & 10.0 & 11.3 & 7.0 \\
\hline
\end{tabular}

${ }^{a}$ Means for 2006 and 2007 experiments are based on three replications, and two replications for 2008 .

A

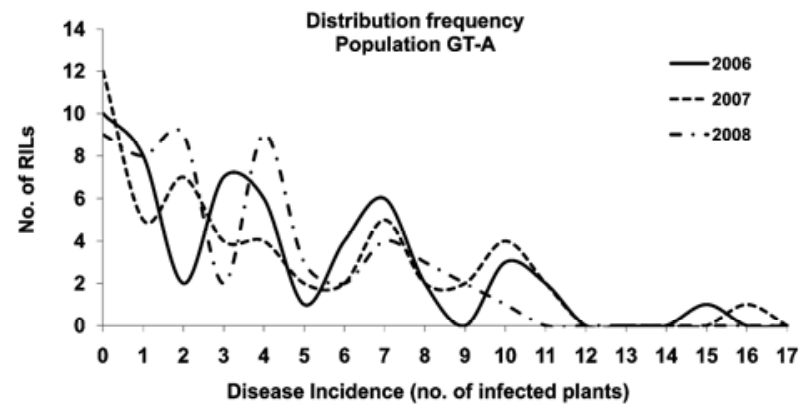

GT-B RILs with resistant reactions averaged across years was 45 and $62 \%$, respectively. Equal proportion of resistant to susceptible RILs is indicative of a single qualitative resistance gene segregating in the population. However, clear, discrete segregation classes matching the disease response of the parents were not obtained. Thus, if an R gene is present it is likely modified by minor genes. Overall, the GT-A population was consistently more susceptible than GT-B across years. This difference between populations suggests that the parents may be heterogeneous for minor genes that cause slight differences in reaction to CTV, and that different parental plants possessing such differences were used in the separate crosses. Select parental populations from individual plants used in the crosses were not maintained so testing of this hypothesis was not tested.

Nine RAPD markers, seven dominant and two codominant that cosegregated with disease reaction among individual lines within the $\mathrm{R}$ and $\mathrm{S}$ bulks were mapped across the $98 \mathrm{~F}_{5: 7}$ GT RILs. These markers formed two linkage groups (Figs. 2 and 3), consisting of five and four markers, respectively, which detected respective major- and minor-effect QTL. The presence of multiple genes where at least one had a major effect supports the observation of skewed distribution in favor of resistant phenotypes depicted in Figure 1.

Five RAPD markers (AE18.950, AE18.435, Q14.973, R15.465, and S11.649) detected the same major-effect QTL in both populations (Table 2). The amplicons for these markers all derived from the resistant parent G122. The QTL was expressed every year, with phenotypic variation explained ranging from 17 to $47 \%$. The QTL had greater effect in population GT-A (37\%) than in GT-B (20\%), perhaps because the former population was more susceptible overall than the latter which enabled greater expression of the QTL (Table 1).

The RAPD markers were found to be very tightly linked with each other. In fact, only one recombination event between AE18 markers and the other three markers was observed for a single RIL in the GT-A population. The linkage group formed using marker data for all 98 RILs combined from both populations revealed $1 \mathrm{cM}$ linkage distance between those markers (Fig. 2).

To facilitate MAS of this major QTL, two RAPD markers (Q14.973 and R15.465) were sequenced in order to convert them to SCAR markers. Only Q14.973 was successfully converted into a 973-bp SCAR marker (GenBank accession no. GU725437) designated SQ14.973, using the protocol described previously (6) (Fig. 4). The extended SCAR primer sequences are as follows: SQ14.973-F 5'-GGACGCTTCATGACATTGGATGAACAG-3' and SQ14.973-R 5'-GGACGCTTCACCCTTTGTGGTATTG-3' where the underlined nucleotides represent the original Q14 decamer primer used in the RAPD reaction. Thermocycling was optimized to the following conditions: a single cycle of $2 \mathrm{~min}$ at $95^{\circ} \mathrm{C}$ followed by 30 cycles of $1 \mathrm{~min}$ at $94^{\circ} \mathrm{C}, 1 \mathrm{~min}$ at $69^{\circ} \mathrm{C}$, and $1 \mathrm{~min}$ at $72^{\circ} \mathrm{C}$.

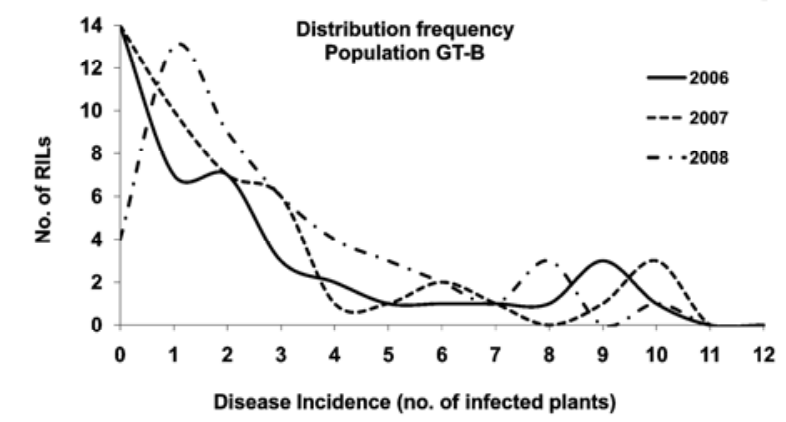

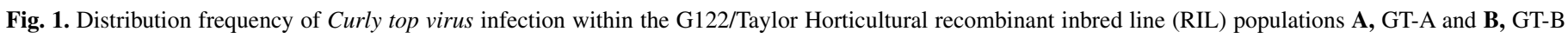
across three field trials conducted in 2006, 2007, and 2008. 
The SQ14.973 SCAR and R15.465 RAPD markers were polymorphic in the BJ (BAT 93/Jalo EEP558) core mapping population. The markers integrated to linkage group 6 and remained tightly linked as observed in the original GT population (Fig. 2).
Interestingly, these markers were in trans linkage orientation in the BJ population, with SQ14.973 amplified in Jalo EEP558 and R15.465 amplified in BAT 93, whereas in the original GT population they were in cis linkage. Integration of the markers to link-

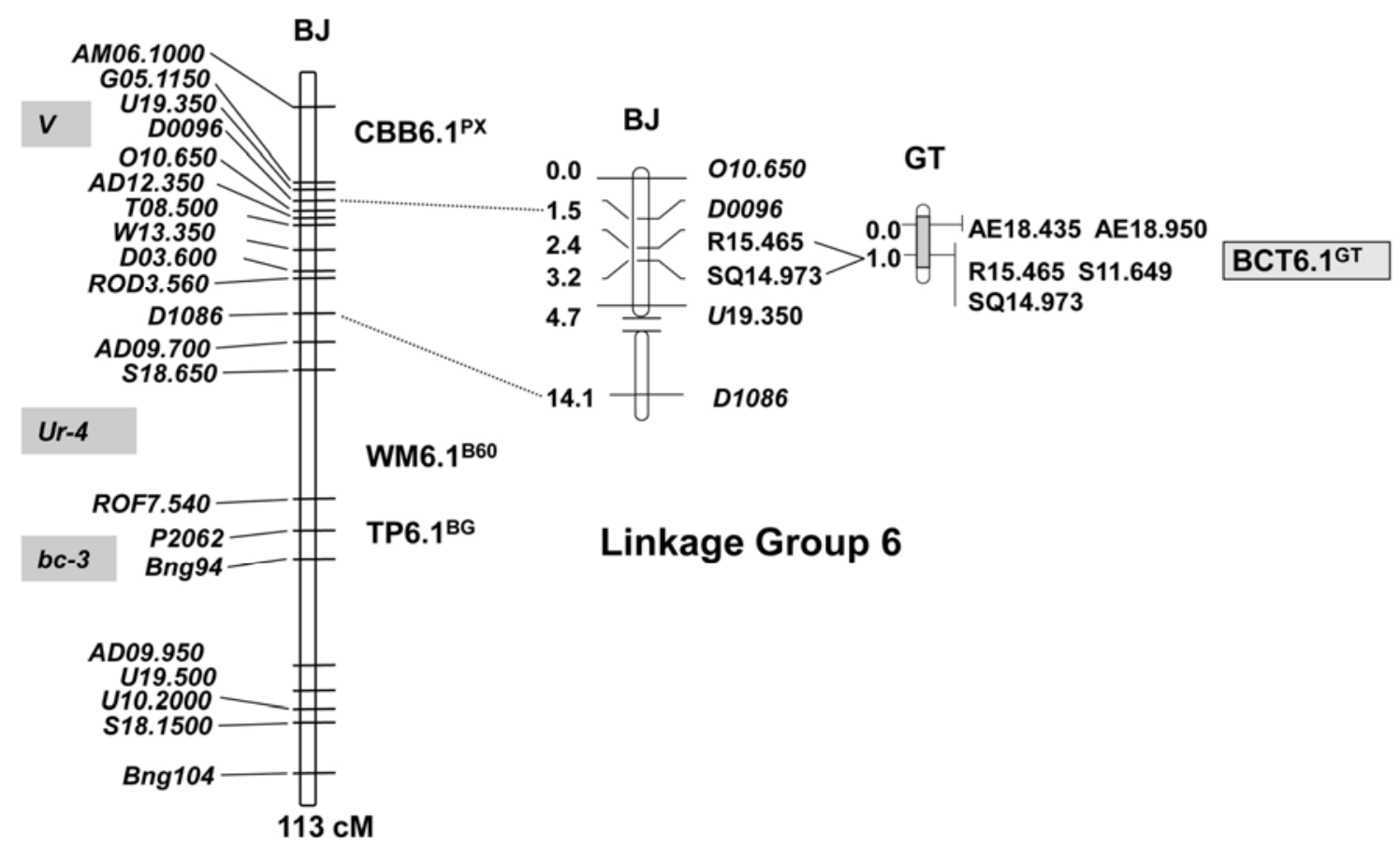

Fig. 2. Partial linkage group of dominant random amplified polymorphism DNA markers AE18.950, AE18.435, R15.465, S11.649, and sequence-characterized amplified region SQ14.973 (right side) associated with the major-effect quantitative trait loci for resistance to Curly top virus mapped in $98 \mathrm{~F}_{5: 7}$ recombinant inbred lines (RILs; G122/Talor Horticultural) (GT population) and position of the R15.465 and SQ14.973 markers integrated within a subsection of the BJ map (middle) relative to the full linkage group B6 (left side) of the Phaseolus core map (80 RILs -BAT 93/Jalo EEP 558) (BJ population). Markers with the prefix Bng (Florida) and $\mathrm{D}$ (Davis) are restriction fragment length polymorphisms, $V$ is the seed color locus, $U r-4$ is the rust resistance gene locus, and $b c-3$ is the gene locus conferring resistance to Bean common mosaic virus and Bean common mosaic necrosis virus. Centimorgans (cM) represent Kosambi map units.

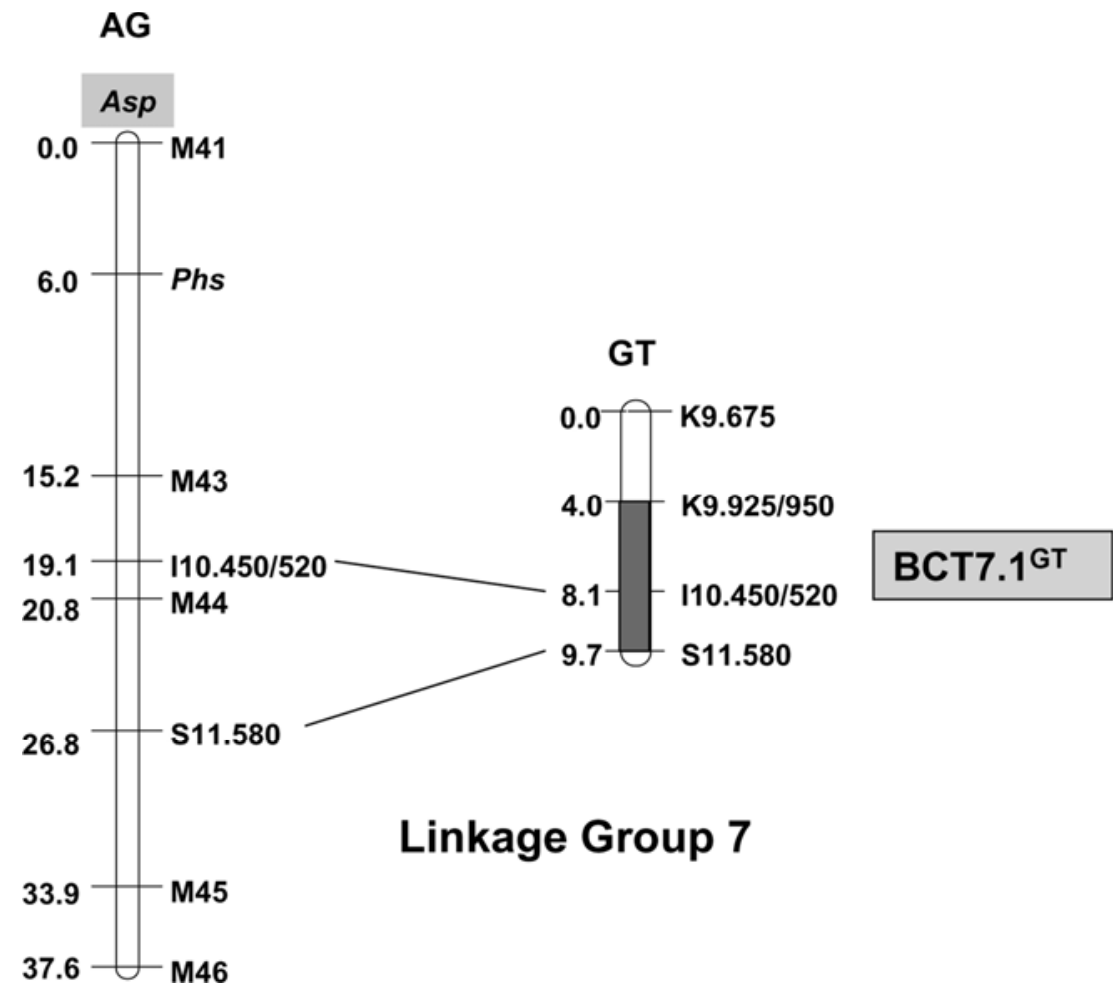

Fig. 3. Partial linkage group of random amplified polymorphism DNA markers I10.450/520, K9.925/950, and S11.580 associated with the minor-effect quantitative trait loci for resistance to Curly top virus mapped in $98 \mathrm{~F}_{5: 7}$ recombinant inbred lines (RILs) G122/Taylor Horticultural (GT population) and position of the markers on linkage group B7 of the A55/G122 (67 RILs) (AG) mapping population. Asp is the gene locus for seed coat shininess. Centimorgans (cM) represent Kosambi map units. 


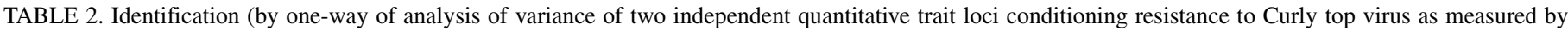

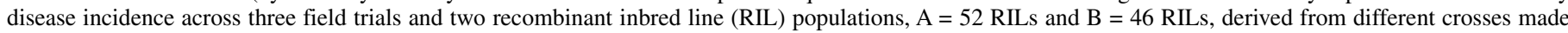
between G122 × Taylor Horticultural ${ }^{\mathrm{a}}$

\begin{tabular}{|c|c|c|c|c|c|c|}
\hline \multirow{3}{*}{$\begin{array}{l}\text { RIL } \\
\text { population }\end{array}$} & \multirow{3}{*}{$\begin{array}{l}\text { Linkage } \\
\text { group }\end{array}$} & \multirow{3}{*}{$\begin{array}{l}\text { Random amplified polymorphism DNA } \\
\text { and sequence-characterized amplified region markers }\end{array}$} & \multirow{3}{*}{$\begin{array}{c}\text { Linkage } \\
\text { distance }(\mathrm{cM})\end{array}$} & \multicolumn{3}{|c|}{ Percent $\left(R^{2}\right)$ phenotypic variation explained } \\
\hline & & & & \multicolumn{3}{|c|}{ Disease incidence } \\
\hline & & & & 2006 & 2007 & 2008 \\
\hline \multirow[t]{5}{*}{ GT-A } & 6 & AE18.435, AE18.950 & 0 & $37.9(P<0.0001)$ & $43.0(P<0.0001)$ & $26.6(P<0.0001)$ \\
\hline & 6 & SQ14.973, SR15.465, S11.649 & 2 & $40.3(P<0.0001)$ & $47.3(P<0.0001)$ & $25.2(P<0.0001)$ \\
\hline & 7 & K9.925/950 & 0 & $11.8(P<0.013)$ & $8.5(P<0.035)$ & ns \\
\hline & 7 & I10.450/520 & 4.1 & $10.7(P<0.018)$ & $8.7(P<0.034)$ & ns \\
\hline & 7 & $\mathrm{~S} 11.580$ & 1.6 & $14.6(P<0.005)$ & $11.8(P<0.013)$ & ns \\
\hline \multirow[t]{4}{*}{ GT-B } & 6 & AE18.435, AE18.950, SQ14.973, SR15.465, S11.649 & 0 & $26.4(P<0.0003)$ & $17.3(P<0.0004)$ & $17.6(P<0.0004)$ \\
\hline & 7 & K9.925/950 & 0 & ns & ns & $15.7(P<0.006)$ \\
\hline & 7 & I10.450/520 & 4.1 & ns & ns & $11.4(P<0.022)$ \\
\hline & 7 & S11.580 & 1.6 & ns & ns & $10.7(P<0.026)$ \\
\hline
\end{tabular}

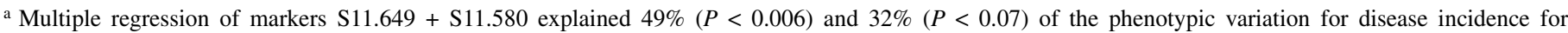
populations GT-A and GT-B, respectively, for 2006; explained 53\% $(P<0.015)$ and $24 \%(P<0.06)$ for populations GT-A and GT-B, respectively, for 2007 ; and markers AE18.435 and K9.925/950 explained 34\% $(P<0.03)$ and 33\% $(P<0.004)$ variation for populations GT-A and GT-B, respectively, for 2008. ns denotes nonsignificant values.

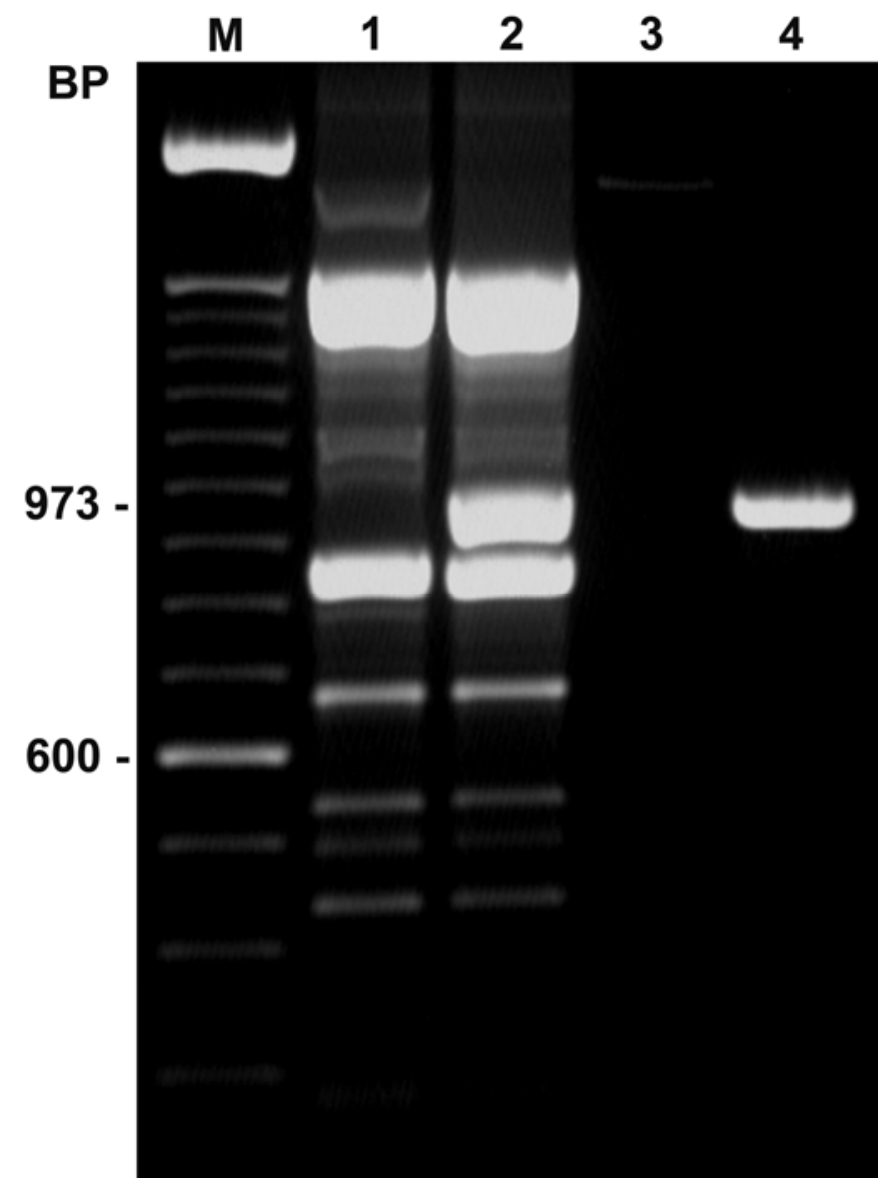

Fig. 4. Agarose gel showing polymerase chain reaction amplification products of genomic DNA from parental lines Taylor Horticultural (susceptible to Curly top virus) and G122 (resistant to Curly top virus). Lanes 1 and 2 show results using rapid amplified polymorphic DNA decamer primer Q14 across Taylor Horticultural and G122, respectively. Lanes 3 and 4 show marker generated by sequence-characterized amplified region primer pair specific to SQ14.973 across Taylor Horticultural and G122, respectively. The 973-bp amplicon observed in lanes 2 and 4 is indicated. Lane M, 100-bp DNA marker.

age group 6 positions the major-effect QTL in close proximity to the $V$ gene locus which conditions seed and flower color, and with a major-effect QTL (BC420) conditioning resistance to common bacterial blight (Xanthomonas axonopodis pv. phaseoli).

Based on recent QTL nomenclature guidelines provided by the Bean Genetics Committee (9), the major-effect QTL conferring resistance to CTV reported here is designated BCT6.1 ${ }^{\mathrm{GT}}$. Introgression of BCT6.1 ${ }^{\mathrm{GT}}$ QTL into market classes such as black bean that are dependent upon presence of the dominant $V$ will be more difficult because of the repulsion linkage between these loci. Combining BCT6. ${ }^{\mathrm{GT}}$ with resistance to common bacterial blight conferred by the BC420 QTL will be similarly affected by linkage in repulsion. Close proximity of these two QTL with major effect against distinct pathogens, viral and bacterial, suggests a cluster of resistance genes with effect against multiple pathogens, may exist in this genomic region of linkage group 6.

The potential utility for MAS of BCT6.1 ${ }^{\mathrm{GT}}$ using the SQ14.973 SCAR was investigated across a wide array of lines and cultivars (Table 3). The SCAR could have wide application for MAS in the Middle American gene pool because none of 44 Middle American lines tested possessed the marker. The marker is less robust for potential MAS in the Andean gene pool because 35\% of Andeanderived materials possessed the SCAR regardless of CTV reaction.

The marker appears to be least useful for MAS in snap beans which are predominantly of Andean origin, because the majority of the snap beans tested possessed SQ14.973. It is common for resistance-linked markers to have limitations for MAS in the genetic backgrounds from whence the tagged genes derive. For example, the Bct gene linked marker is not useful for MAS in the Middle American gene pool because the gene originates from this gene pool (8). Absence of the SQ14.973 marker in the Middle American gene pool and wide presence across Andean germplasm indicates BCT6. ${ }^{\mathrm{GT}}$ is of Andean origin, which is consistent with the fact that the G122 landrace also is of Andean origin.

Two dominant RAPD markers K9.675 and S11.580, and two codominant RAPD markers I10.450/520 and K9.925/950, formed another linkage group which detected a QTL with minor effect (Fig. 3). The phenotypic variation for disease incidence explained by the QTL was relatively low ranging from 8 to $15 \%$ (Table 2). In addition, expression of the QTL was inconsistent across populations and years which is typical for a minor-effect QTL. The QTL was detected in 2006 and 2007 but not in 2008 in the GT-A population, and was only detected in 2008 in GT-B. Detection of the QTL associates with those years with higher overall disease incidence for a particular population. Higher mean disease incidences were observed in 2006 and 2007 for GT-A, and in 2008 for GT-B.

To integrate this QTL to the Phaseolus core map, the RAPD markers I10.450/520 and S11.580 were mapped across the AG population (7). The AG population, which shares the parent G122, was used because none of the markers for this linkage group were discernible in the BJ mapping population. The RAPD markers mapped in the AG population integrated to linkage group 7 . The 
TABLE 3. Andean and Middle American bean (Phaseolus vulgaris) lines assayed for the SQ14.973 sequence-characterized amplified region (SCAR) marker associated with a major-effect quantitative trait loci conditioning resistance to Curly top virus

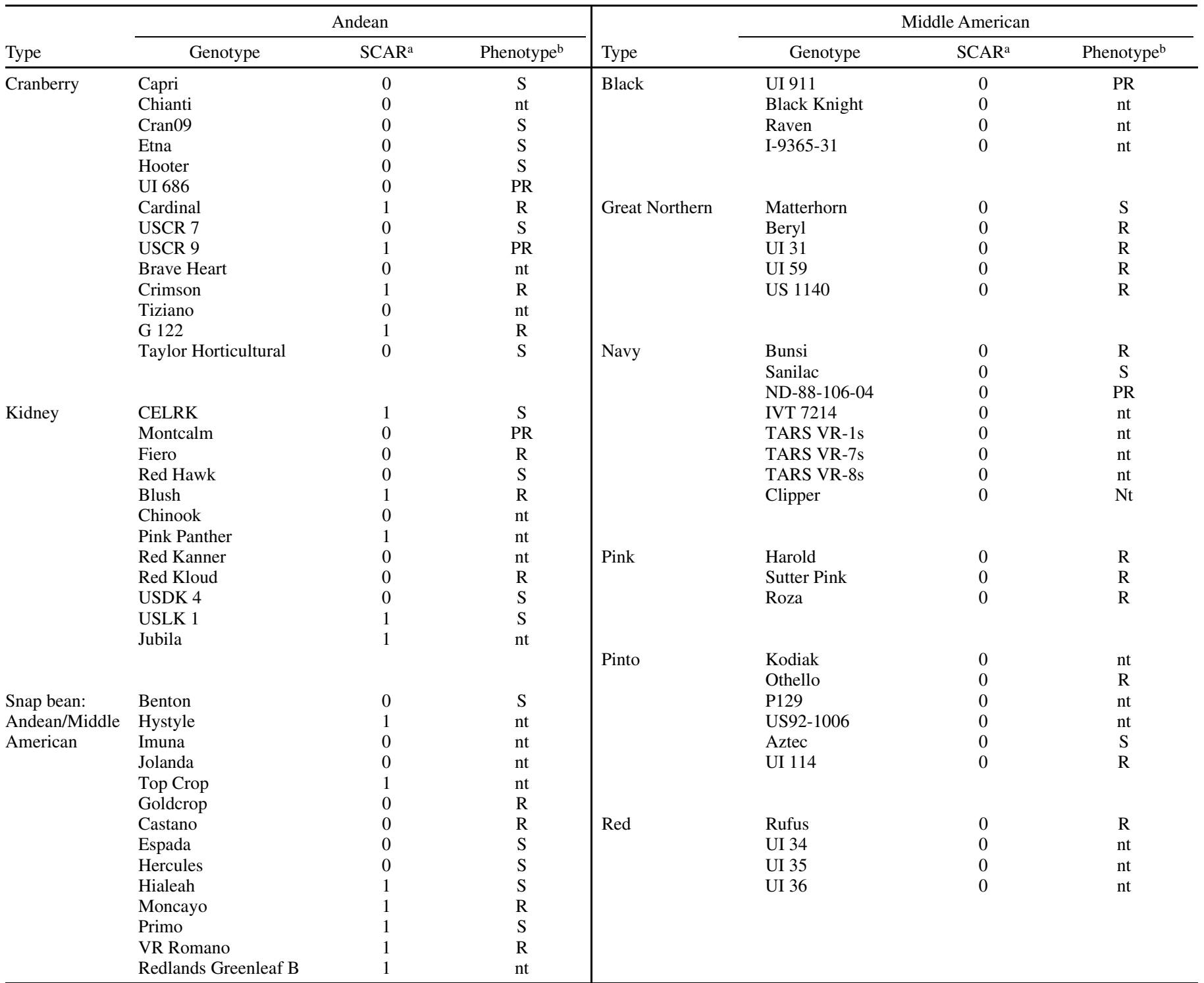

${ }^{\mathrm{a}}$ Marker present $=1$; marker absent $=0$.

${ }^{\mathrm{b}} \mathrm{R}=$ resistant; $\mathrm{S}=$ susceptible; $\mathrm{PR}=$ partially resistant; $\mathrm{nt}=$ not tested.

QTL is designated BCT7.1 ${ }^{\mathrm{GT}}$ to reflect the first QTL for CTV resistance located on linkage group 7.

Other QTL conferring resistance to geminiviruses Bean dwarf mosaic virus (BDMV) and Bean golden yellow mosaic virus have been located on linkage group 7 (8). In addition, the Bct gene conferring dominant resistance to CTV is located in the vicinity of these QTL. The Bct gene itself was associated with quantitative resistance to BDMV (8). The BCT7.1 ${ }^{\mathrm{GT}}$ QTL is in a different region of the linkage group than where the other resistances are located. Using the Asp locus for seed brilliance, Phaseolin seed protein locus $(P h s)$, and $P$ seed color locus, as reference points, BCT7.1 ${ }^{\text {GT }}$ occurs between $P$ and $P h s$, and $B c t$ and the other geminivirus resistance QTL are located between $P h s$ and Asp.

The detection of QTL BCT6.1 ${ }^{\mathrm{GT}}$ and BCT7. $1^{\mathrm{GT}}$ independent of other virus resistance genes clearly indicates that G122 possesses novel resistance to CTV. These QTL provide breeders with an additional and heritable source of resistance to CTV in common bean and is significant given that novel resistance for combating CTV is severely lacking. This quantitative resistance should eventually be combined with other qualitative resistance sources such as the Bct gene to obtain bean cultivars with enhanced resis- tance to CTV. Markers for Bct and the QTL described herein will enable MAS to facilitate breeding for enhanced CTV resistance.

\section{LITERATURE CITED}

1. Bennett, C. W. 1971. The Curly Top Disease of Sugarbeet and Other Plants. Monograph No. 7. American Phytopathological Society, St. Paul, MN.

2. Carsner, E., and Stahl, C. F. 1924. Studies on curly-top disease of the sugar beet. J. Agric. Res. 28:297-320.

3. Creamer, R., Luque-Williams, M., and Howo, M. 1996. Epidemiology and incidence of beet curly top geminivirus in naturally infected weed hosts. Plant Dis. 80:533-535.

4. Fauquet, C. M., Bisaro, D. M., Briddon, R. W., Brown, J. K., Harrison, B. D., Rybicki, E. P., Stenger, D. C., and Stanley, J. 2003. Revision of taxonomic criteria for species demarcation in the family Geminiviridae, and an updated list of begomovirus species. Arch. Virol. 148:405-421.

5. Freyre, R., Skroch, P. W., Geffroy, V., Adam-Blondon, A. F., Shirmohamadali, A., Johnson, W. C., Llaca, V., Nodari, R. O., Pereira, P. A., Tsai, S. M., Thome, J., Dron, M., Nienhuis, J., Vallejos, C. E., and Gepts, P. 1998. Towards an integrated linkage map of common bean. 4. Development of a core linkage map and alignment of RFLP maps. Theor. Appl. Genet. 97:847-856.

6. Larsen, R. C., and Miklas, P. N. 2004. Generation and molecular mapping 
of a sequence characterized amplified region marker linked with the $B c t$ gene for resistance to Beet curly top virus in common bean. Phytopathology 94:320-325.

7. Miklas, P. N., Johnson, W. C., Delorme, R., and Gepts, P. 2001. QTL conditioning physiological resistance and avoidance to white mold in dry bean. Crop Sci. 41:309-315.

8. Miklas, P. N., Seo, Y.-S., and Gilbertson, R. L. 2009. Quantitative resistance to Bean dwarf mosaic virus in common bean is associated with the Bct gene for resistance to Beet curly top virus. Plant Dis. 93:645-648.

9. Porch, T. 2009. QTL nomenclature. In: BIC Genetics Committee minutes: Annu. Rept. Bean Improv. Coop. 52:iii.

10. Sambrook, J., Fritsch, E. F., and Maniatis, T. (eds.) 1989. Molecular Cloning: A Laboratory Manual. 2nd ed. Cold Spring Harbor Laboratory, Cold Spring Harbor, NY.

11. SAS Institute, Inc. 2004. SAS-OnlineDoc 9.1.3. SAS Institute Inc., Cary, NC.

12. Schultz, H. K., and Dean, L. L. 1947. Inheritance of curly top disease reaction in the bean, Phaseolus vulgaris. J. Am. Soc. Agron. 39:47-51.

13. Silbernagel, M. J., and Morales, F. J. 2005. Curly top virus. Pages 77-79 in: Compendium of Bean Diseases. H. F. Schwartz, ed. American Phytopathological Society, St. Paul, MN.

14. Stanley, J., Bisaro, D. M., Briddon, R. W., Brown, J. K., Fauquet, C. M.,
Harrison, B. D., Rybicki, E. P., and Stenger, D. C. 2005. Family Geminiviridae. Page 1259 in: Virus Taxonomy: Classification and Nomenclature of Viruses. The Eighth Report of the International Committee on Taxonomy of Viruses. Academic Press, Boston.

15. Stenger, D. C. 1994. Complete nucleotide sequence of the hypervirulent CFH strain of beet curly top virus. Mol. Plant-Microbe Interact. 7:154-157.

16. Stenger, D. C. 1998. Replication specificity elements of the Worland strain of beet curly top virus are compatible with those of the $\mathrm{CFH}$ strain but not those of the Cal/Logan strain. Phytopathology 88:11741178.

17. Stenger, D. C., Carbonaro, D., and Duffus, J. E. 1990. Genomic characterization of phenotypic variants of beet curly top virus. J. Gen. Virol. 71:2211-2215.

18. Stenger, D. C., and McMahon, C. L. 1997. Genotypic diversity of beet curly top virus populations in the western United States. Phytopathology 87:737-744.

19. Stenger, D. C., and Ostrow, K. M. 1996. Genetic complexity of a beet curly top virus population used to assess sugar beet cultivar response to infection. Phytopathology 86:929-933.

20. Van Ooijen, J. W. 2006. JoinMap 4, Software for the calculation of genetic linkage maps in experimental populations. Kyazma B.V., Wageningen, Netherlands. 